\title{
Physicochemical and microbiological characterization, and evaluation of the antibacterial and antioxidant activity of propolis produced in two seasons and two areas of the eastern edge of the Sonoran Desert
}

\author{
Caracterización fisicoquímica y microbiológica, y evaluación de la actividad antibacteriana \\ y antioxidante del propóleos producido en dos estaciones y dos áreas del borde oriental \\ del Desierto de Sonora
}

\begin{abstract}
Rey David Vargas-Sánchez ${ }^{1,2 *}$, Gastón R. Torrescano-Urrutia ${ }^{1}$ and Armida Sánchez Escalante ${ }^{1}$
Coordinación de Tecnología de Alimentos de Origen Animal (CTAOA), Centro de Investigación en Alimentación y Desarrollo, A.C. Carretera Gustavo Enrique Astiazarán Rosas, No. 46, Col. La Victoria, CP. 83304, Hermosillo, Sonora, México.

CONACyT Research Fellow - CIAD.
\end{abstract}

\section{ABSTRACT}

This study determined the effects of season and collection location on physicochemical quality and microbiological properties of raw propolis, and the biological activity of propolis extracts. The total phenolic compounds (TPC) and total flavonoid content (TFC) were measured, and antioxidant activity was evaluated by the free-radical scavenging activity (FRSA) and reducing power ability (RPA). The antibacterial activity was determined against Gram-positive (Staphylococcus aureus and Listeria monocytogenes) and Gram-negative (Escherichia coli and Salmonella typhimurium) bacteria. The results showed that season affect physicochemical properties, but no different in microbial counts of raw propolis. Propolis extracts collected in both regions during summer had the greatest effect against $S$. aureus (>17 $\mathrm{mm}$ of inhibition zone). In addition, propolis extracts from location 2 and collected during summer exhibit the highest TPC and TFC $(>150$ and $250 \mathrm{mg} / \mathrm{g}$, respectively), as well as highest FRSA ( $>70 \%$ of radical inhibition) and RPA ( $>0.2$ abs). In conclusion, the season and collection location affect the physicochemical properties of propolis and extract bioactivities of propolis.

Keywords: Propolis, Phenolic compound, Antibacterial, Antioxidant

\section{RESUMEN}

Esta investigación determinó los efectos de la estación y el área de colecta sobre la calidad fisicoquímica y microbiológica del propóleos crudo, y la actividad biológica de los extractos de propóleos. El contenido de compuestos fenólicos totales (CFT) y de flavonoides totales (CFvT) fue medido en los extractos de propóleos; así como la actividad antioxidante, mediante la actividad de eliminación de radicales libres (AERL) y la habilidad de poder reductor (HPR). La actividad antibacteriana se determinó contra bacterias Gram-positivas (Staphylococcus aureus y Listeria monocytogenes) y Gramnegativas (Escherichia coli y Salmonella typhimurium). Los resultados mostraron que la estación afecta las propiedades fisicoquímicas, sin encontrarse diferencias en los recuentos microbianos del propóleos crudo. Los extractos recolectados en ambas regiones durante el verano tuvieron el mayor efecto contra S. aureus (>17 mm de zona de inhibición). Además,

Volumen XXII, Número 3 los extractos de propóleos de la zona 2 y recolectados durante el verano mostraron el mayor CFT and CFvT (>150 y 250 $\mathrm{mg} / \mathrm{g}$, respectivamente), así como la más alta AERL (>70\% de inhibición de radicales libres) y HPR ( $>0.2$ abs). En conclusión, la estación y área de colecta afectan las propiedades fisicoquímicas y bioactividad de los extractos de propóleos.

Palabras clave: Propóleos, Compuestos fenólicos, Antibacteriano, Antioxidante

\section{INTRODUCTION}

"Propolis" is etymologically derived from the Greek pro-, in defense, and polis-, the city, which means in defense of the city or hive (Ghisalberti, 1979; Bankova et al., 2019). This resinous mixture is produced by the European honey bee (Apis mellifera) from beeswax, saliva, and the exudate of various plant sources, for use primarily as a sterilizing agent and a sealant in the hive. Some tropical bees (especially Melipona spp.) also produce a form of propolis, and the Australian stingless bee Tetragonula carbonaria produces propolis too. The plant origins of propolis have been observed since the early 1900s, although the use of propolis dates back to at least 300 BC (Ghisalberti, 1979).

Several definitions of propolis exist; in the United States legislation (USDA, 1985), propolis is "a gum that is gathered by bees from various plants", while Foods Standards Australia and New Zealand (FSANZ), formerly Australia and New Zealand Food Authority (ANZFA, 2000), defines propolis as "a resinous substance collected by worker honey bees from the growing parts of trees and shrubs, modified by the bees and then used by the bees to seal their hive". According to the Salvadorian regulations (NSO, 2003), propolis is "the product originated from resinous, gummy and balsamic substances, collected by honey bees, from buds and exudations of bark, leaves and other parts of the plants, to which the bees add salivary secretions and wax for the final elaboration of propolis". Moreover, the Mexican regulations (NOM, 2017) define propolis as "the resinous substance collected and processed by bees from the vegetation surrounding the apiary".

Actually, the advance on medicinal uses of propolis as an anticancer, antitumor, anti-inflammatory, cardioprotective and neuroprotective effects, has generated an

*Autor para correspondencia: Rey David Vargas Sánchez Correo electrónico: rey.vargas@ciad.mx

Recibido: 10 de diciembre de 2019 
increase in propolis consumption, consequently increased the requirements for its production and commercialization (ANZFA, 2000; Braakhuis, 2019; NOM, 2017). In functional food market, propolis extracts have been proposed as an ingredient against foodborne pathogens, bacteria, and disease, as well as an antifungal or oxidative stabilizer against lipid oxidation (Braakhuis, 2019; Cottica et al., 2019; Pérez et al., 2019). However, the pharmacological and preservative properties of propolis extracts can be affected by plant resin (Drescher et al., 2019), pollen (Tugba-Degirmencioglu et al., 2019), geographical origin (Letullier et al., 2020), harvest method and solvent extraction (Papotti et al., 2012), as well as seasonality and environmental conditions of the collection area (Seidel et al., 2008; de Souza et al., 2014).

Raw propolis can be classified according to its botanical origin, geographical origin, and color (NSO, 2003). In addition, in some countries there are recognized regulations that indicate the descriptors the raw propolis and their extracts must meet, such as microbial, sensory, physicochemical parameters and biological properties (NSO, 2003; NOM, 2017).

This investigation evaluated the microbial load and physicochemical parameters of raw propolis collected in two seasons and from two zones of the Sonoran Desert, and the antibacterial and antioxidant potential of propolis extracts.

\section{MATERIALS AND METHODS \\ Chemicals and reagents}

All utilized chemicals were of analytical grade. FolinCiocalteu's reagent, $\mathrm{Na}_{2} \mathrm{CO}_{3^{\prime}}$ 2,2-diphenyl-1-picrylhydrazyl (DPPH), ascorbic acid (Asc), butylated hydroxytoluene (BHT), $\mathrm{AlCl}_{3^{\prime}}, \mathrm{FeCl}_{3}, \mathrm{NaOH}$, trichloroacetic acid, $\mathrm{NaNO}_{2}$, ethanol, $n$ hexane, petroleum ether, plate count agar (PCA), brain heart infusion broth (BHI), and Muller-Hinton agar (MHA) were purchased from Sigma-Aldrich (St. Louis, MO, USA). Gallic acid, caffeic acid phenethyl ester (CAPE), and quercetin (Qc) were obtained from Sigma Chemical Co. (St. Louis, MO, USA). Pinocembrin $(\mathrm{Pn})$ was purchased from Indofine Chemical Company, Inc. (Hillsborough, NJ, USA).

\section{Propolis collection}

Propolis samples were collected from the Sonoran Desert, central Sonora, during two seasons of the year ( $\mathrm{S}$, summer; W, winter; 2017). The location presents desert climate characteristics, and the sampling site is surrounded by foothills or thorn-scrub, dominated by Fabaceae, Cactaceae, Malvaceae, and Asteraceae families (Vargas-Sánchez et al., 2016). In each season, propolis samples were collected from two collection locations: 1, Pueblo of Alamos (29 $8^{\prime} 51.36^{\prime \prime}$ $\mathrm{N}, 110^{\circ} 7^{\prime} 26^{\prime \prime} \mathrm{W} ; 636 \mathrm{~m}$ a.s.l.); 2, Rancho Viejo $\left(29^{\circ} 7^{\prime} 19.72^{\prime \prime} \mathrm{N}\right.$, $110^{\circ} 16^{\prime} 58.35^{\prime \prime}$ W; $476 \mathrm{~m}$ a.s.l.), each with 15 hives.

\section{Physicochemical analysis Instrumental color evaluation}

The lightness $\left(L^{*}\right)$, redness $\left(a^{*}\right)$, and yellowness $\left(b^{*}\right)$ of raw propolis were measured under a D65 illuminant using a spectrophotometer (CM 508d, Konica Minolta, Inc., Tokyo,
Japan) with $10^{\circ}$ observer angle. In total, ten measurements were performed on the surface of each sample (CIE, 1978).

\section{Chemical proximate analysis}

The moisture and ash contents, wax, resin, and mechanical impurities of raw propolis samples were determined according to AOAC (2005) and Lozina et al. (2010). Propolis samples $(10 \mathrm{~g})$ were cut into small pieces. Moisture and ash contents were gravimetrically determined by oven-drying at $100{ }^{\circ} \mathrm{C}$ for $8 \mathrm{~h}$ (FE-293A, Felisa, Guadalajara, Jal., Mexico) and incinerating in a muffle furnace at $550^{\circ} \mathrm{C}$ for $3 \mathrm{~h}$ (AR-340, Felisa, Guadalajara, Jal., México), respectively. Afterward, the samples were cooled and weighed. Wax content was determined by extraction with petroleum ether at $40-60^{\circ} \mathrm{C}$ for $3 \mathrm{~h}$ (Goldfish Fat Extractor, Labconco Corp., Kansas, MO., USA). After removing the waxes, the samples were placed in an oven at $100{ }^{\circ} \mathrm{C}$ for $3 \mathrm{~h}$, cooled, and weighed. To estimate the resin contents and mechanical impurities, raw propolis samples were extracted with a mixture of $n$-hexane and ethanol $(1: 1, v / v)$. The insoluble residue (impurities) and residue soluble filtered (resins) were dried at $100^{\circ} \mathrm{C}$ for $3 \mathrm{~h}$, cooled, and weighed.

\section{Microbiological analysis}

Mesophilic and psychrotrophic bacteria counts were measured according to NOM (1994a). Each propolis sample was diluted with $0.1 \%$ of saline peptone water $(1: 10, \mathrm{w} / \mathrm{v})$, and homogenized $(1 \mathrm{~min})$. Serial dilutions were prepared with $0.1 \%$ of peptone water, and $1 \mathrm{~mL}$ of appropriate dilutions were pour-plated using standard PCA. Plates were incubated at $37^{\circ} \mathrm{C}$ for $48 \mathrm{~h}$, and $7^{\circ} \mathrm{C}$ for 10 days for mesophilic and psychrotrophic growth, respectively. Additionally, Staphylococcus aureus counts were measured according to NOM (1994b). Each appropriate dilution was pour-plated using Baird-Parker agar, spread, and incubated at $35^{\circ} \mathrm{C}$ for $24 \mathrm{~h}$. Counts were expressed as colony-forming units per gram of raw propolis (CFU/g).

\section{Preparation of propolis extract}

Raw propolis samples were cut into small pieces and extracted twice by maceration (300 rpm for 3 days) with ethanol $(1: 10, w / v)$ at room temperature $\left(25^{\circ} \mathrm{C}\right)$. The resulting solution was filtered (Whatman 4 filter paper) and concentrated under reduced pressure at $60^{\circ} \mathrm{C}$ on a rotary evaporator (R-200, Büchi, Flawil, Switzerland). The obtained propolis extract was washed three times with $n$-hexane to remove the waxes, and resulting solution was centrifuged at 4,500 $\mathrm{x} \mathrm{g} / 4^{\circ} \mathrm{C}$ for20 min (Beckman Coulter Allegra X-12, Fullerton, (A., USA) and concentrated under reduced pressure at $60^{\circ} \mathrm{C}$. The final propolis extract was lyophilized (freeze dryer model 77540, Labconco Corp., Kansas, MO., USA), and stored at -20 ${ }^{\circ} \mathrm{C}$ in the dark, until analysis (Hernández et al., 2007).

\section{Phenolic composition \\ Total phenolic content}

Total phenolic content (TPC) of propolis extracts was measured using the Folin-Ciocalteu's method (Ainsworth \& 
Gillespie, 2007). Each extract $(100 \mu \mathrm{L}$, at $62.5,125$, and $250 \mu \mathrm{g}$ of dried propolis extracts $/ \mathrm{mL}$ of ethanol) was homogenized with $250 \mu \mathrm{L}$ of distilled water and $250 \mu \mathrm{L}$ of Folin-Ciocalteu's reagent $(0.25 \mathrm{~N})$, and neutralized with $0.750 \mu \mathrm{L}$ of $\mathrm{Na}_{2} \mathrm{CO}_{3}(7 \%$ $\mathrm{w} / \mathrm{v})$. The resulting solution was mixed on a vortex at 10,000 rpm for 1 min (Fisher Scientific, Pittsburgh, PA., USA), then incubated at $25^{\circ} \mathrm{C}$ for $30 \mathrm{~min}$, in the dark. The absorbance was measured using a spectrophotometer at $765 \mathrm{~nm}$ (Spectronic Genesys 5, Thermo Electron Corp., Madison, Wis., USA). The TPC was expressed as milligrams of gallic acid equivalents per gram of dried extract (mg GAE/g).

\section{Total flavonoid content}

Total flavonoid content (TFC) of propolis extracts was measured using the colorimetric assay described by Zhishen et al. (1999) with slight modifications. Each extract $(500 \mu \mathrm{L}$, at $62.5,125$, and $250 \mu \mathrm{g}$ of dried propolis extract $/ \mathrm{mL}$ of ethanol) was homogenized with $1 \mathrm{~mL} \mathrm{NaNO} 2(5 \% \mathrm{w} / \mathrm{v}), 1 \mathrm{~mL} \mathrm{AICl}$ $(10 \% \mathrm{w} / \mathrm{v})$, and $10 \mathrm{~mL} \mathrm{NaOH}(1 \mathrm{M})$. The resulting solution was mixed with $12 \mathrm{~mL}$ of $70 \%$ ethanol and incubated at $25^{\circ} \mathrm{C}$ for $15 \mathrm{~min}$ in the dark. The absorbance was measured at $510 \mathrm{~nm}$, and results were expressed as milligrams of Qc equivalents per gram of dried extract (mg QcE/g)

\section{Antibacterial activity}

Antibacterial activity was assayed using the agar well diffusion method (Rennie et al., 2012) with slight modifications. Bacteria strains, Staphylococcus aureus ATCC 29213B, Listeria monocytogenes ATCC 7644, Escherichia coli ATCC 25922, and Salmonella typhimurium ATCC 14028 were inoculated in liquid nutrient Broth (BHI agar) and incubated at $37^{\circ} \mathrm{C}$ for $24 \mathrm{~h}$. Afterward, cellular suspension $\left(1 \times 10^{6} \mathrm{CFU} / \mathrm{mL}\right)$ was grown on MHA plates by incubation at $37^{\circ} \mathrm{C}$ for $24 \mathrm{~h}$. Later, wells of $5 \mathrm{~mm}$ were punched in the agar plates using a sterile glass borer, and each extract $(50 \mu \mathrm{L}$, at $62.5,125$, and $250 \mu \mathrm{g}$ of dried propolis extract $/ \mathrm{mL}$ of ethanol) was added to the wells. The plates were incubated at $37^{\circ} \mathrm{C}$ for $24 \mathrm{~h}$. CAPE, $\mathrm{Pn}$, and Qc were used as antibacterial standards (at $250 \mu \mathrm{g} /$ $\mathrm{mL}$ ). Inhibition zone $(\mathrm{mm})$ around the well was recorded.

\section{Antioxidant activity \\ Free-radical scavenging activity}

The DPPH free-radical scavenging activity (FRSA) assay described by Molyneux (2004) was conducted, with slight modifications. Each extract $(100 \mu \mathrm{L}$, at 62.5, 125, and $250 \mu \mathrm{g}$ of dried propolis extract $/ \mathrm{mL}$ of ethanol) was homogenized with $100 \mu \mathrm{L}$ of DPPH solution $(300 \mu \mathrm{M})$, and incubated at 25 ${ }^{\circ} \mathrm{C}$ for $30 \mathrm{~min}$, in the dark. After, absorbance was measured at $520 \mathrm{~nm}$, and the FRSA was expressed as follows: FRSA (\%) = $\left[A b s_{0}-A b s_{s} / A b s_{0}\right] \times 100$, where $A b s_{0}$ is control absorbance at $t=0 \mathrm{~min}$, and $A b s$ is antioxidant absorbance at $t=30 \mathrm{~min}$. In addition, Asc, BHT, CAPE, Pn, and Qc were used as antioxidant standards (at $250 \mu \mathrm{g} / \mathrm{mL}$ ).

\section{Reducing power ability}

Reducing power ability (RPA) was measured using the Prussian blue method (Oyaizu, 1986) with slight modifica- tions. Each extract $(100 \mu \mathrm{L}$, at $62.5,125$, and $250 \mu \mathrm{g}$ of dried propolis extract $/ \mathrm{mL}$ of ethanol) was homogenized with 300 $\mu \mathrm{L}$ of phosphate buffer $(0.2 \mathrm{M}, \mathrm{pH} 6.6)$ and $300 \mu \mathrm{L}$ of potassium ferricyanide $(1 \% \mathrm{w} / \mathrm{v})$, and incubated in a water bath at $50{ }^{\circ} \mathrm{C}$ for $20 \mathrm{~min}$. The resulting solution was mixed with 300 $\mu \mathrm{L}$ of trichloroacetic acid $(10 \% \mathrm{w} / \mathrm{v})$, and centrifuged $(4,200$ $\times g, 4^{\circ} \mathrm{C}$, for $\left.10 \mathrm{~min}\right)$. The supernatant $(500 \mu \mathrm{L})$ was homogenized with $100 \mu \mathrm{L}$ of distilled water and $250 \mu \mathrm{L} \mathrm{FeCl}$ (0.1\%). The absorbance was measured at $700 \mathrm{~nm}$, and results were expressed as absorbance (abs) at the same wavelength.

\section{Statistical analysis}

All experiments were conducted in triplicate, with at least three independent experiments, and results were expressed as mean \pm standard deviation. Data were subjected to analysis of variance, according to a two factorial design using National Center for Social Statistics Software 2007v (Kaysville, UT., USA). Normal distribution and variance homogeneity was previously tested (Shapiro-Wilk test). The season of propolis collection (summer or winter) and the location zone (Pueblo of Álamos and Rancho Viejo) were fixed terms in the model. A Tukey-Kramer multiple comparison test was performed to determine the significance of mean values at $a=0.05$.

\section{RESULTS AND DISCUSSION Physicochemical and microbial counts of propolis sam- ples}

Raw propolis can vary on color, from red to yellowreddish, yellow-dark, brown-green, brown, or black, depending on its geographical and plant origin (Falcão et al., 2013; NOM, 2017). The color, odor, flavor, and consistency are sensory parameters of raw propolis used for its classification in Mexico (NSO, 2003; NOM, 2017). From the color data provided in Table 1, raw propolis samples collected during winter (PW1 and PW2) showed the highest $L^{*}$ values $(P<0.05)$, while $a^{*}$ values were similar among all samples $(P>0.05)$. There was no seasonal effect $(P>0.05)$ on the $b^{*}$ values of the samples, whereas this parameter was influenced by the collection location $(P<0.05)$, with PW2 and PS2 registering the highest values $\left(b^{*}=8.8\right)$. In agreement, Falcão et al. (2013) published the first report of propolis color evaluation in the CIELab system and indicated that this method is quick and reliable for quality recognition and could be used for propolis differentiation.

Data obtained on the proximate composition of the collected propolis samples (Table 1) revealed PS1 and PS2 samples had the lowest moisture content $(P<0.05)$, which can be related to the weather conditions (temperature and humidity) during the collection (Vargas-Sánchez et al., 2016). In the current study, propolis samples collected during winter showed the highest $(P<0.05)$ contents of ash and mechanical impurities (10.3 and $20.8 \%$, respectively), which can be explained by the presence of vegetal material (leaves and woods) in the samples, insect remains, and soil, 
among others (NOM, 2017). Although there were no notable differences $(P>0.05)$ in the wax content $(27.4 \%)$ among the samples, propolis samples collected during summer showed the highest $(P<0.05)$ resin content $(46.2 \%)$, which is associated with the presence of phenolic compounds (Lozina et al., 2010; Bankova et al., 2019). According to NSO regulations (2003), the moisture (maximum 8\%), wax (maximum 30\%), and mechanical impurities (maximum 30\%) are within the allowed parameters. Additionally, the results of Table 2 show no significant effect $(P>0.05)$ between season $\times$ location region on mesophilic $(<250 \mathrm{CFU} / \mathrm{g})$, psychrotrophic $(<250$ $\mathrm{CFU} / \mathrm{g}$ ) and S. aureus ( $<10 \mathrm{CFU} / \mathrm{g}$ ) counts. According to the NSO (2003), propolis samples showed mesophilic $(<10,000$ CFU/g), psychrotrophic (not established), and S. aureus counts (100 CFU/g) within the permitted limits.

\section{Phenolic composition of propolis extracts}

Several works have reported that propolis extracts include many bioactive phenolic compounds, including phenolic acids and flavonoids (Ghisalberti, 1979; Hernández et al., 2007; Seidel et al., 2008; Tugba-Degirmencioglu et al., 2019; Papotti et al., 2012; Pérez et al., 2019). As shown in Figu-

Table 1. Physicochemical parameters of raw propolis samples. Tabla 1. Parámetros fisicoquímicos de muestras de propóleos.

\begin{tabular}{lcccc}
\hline Item & PW1 & PS1 & PW2 & PS2 \\
\hline \multicolumn{4}{c}{ Color } \\
\hline$L^{*}$ & $29.1 \pm 1.0^{\mathrm{b}}$ & $27.8 \pm 0.1^{\mathrm{a}}$ & $34.2 \pm 0.8^{\mathrm{b}}$ & $28.9 \pm 1.1^{\mathrm{a}}$ \\
\hline$a^{*}$ & $2.6 \pm 0.3^{\mathrm{a}}$ & $2.1 \pm 0.6^{\mathrm{a}}$ & $3.4 \pm 0.7^{\mathrm{a}}$ & $3.5 \pm 0.7^{\mathrm{a}}$ \\
\hline$b^{*}$ & $4.9 \pm 1.0^{\mathrm{a}}$ & $3.6 \pm 0.8^{\mathrm{a}}$ & $8.0 \pm 1.2^{\mathrm{b}}$ & $9.6 \pm 1.1^{\mathrm{b}}$ \\
\hline & & Proximate composition \\
\hline Moisture & $4.5 \pm 1.0^{\mathrm{b}}$ & $2.5 \pm 0.4^{\mathrm{a}}$ & $4.8 \pm 0.2^{\mathrm{b}}$ & $2.4 \pm 0.2^{\mathrm{a}}$ \\
\hline Ash & $10.3 \pm 1.1^{\mathrm{b}}$ & $6.5 \pm 0.9^{\mathrm{a}}$ & $10.4 \pm 0.5^{\mathrm{b}}$ & $7.1 \pm 0.7^{\mathrm{b}}$ \\
\hline Waxes & $28.6 \pm 1.9^{\mathrm{a}}$ & $27.0 \pm 2.4^{\mathrm{a}}$ & $29.0 \pm 2.5^{\mathrm{a}}$ & $27.0 \pm 2.7^{\mathrm{a}}$ \\
\hline Resins & $34.5 \pm 1.5^{\mathrm{a}}$ & $46.8 \pm 2.0^{\mathrm{b}}$ & $35.0 \pm 1.9^{\mathrm{a}}$ & $45.7 \pm 1.1^{\mathrm{b}}$ \\
\hline $\begin{array}{l}\text { Mechanical } \\
\text { impurities }\end{array}$ & $21.3 \pm 1.1^{\mathrm{b}}$ & $17.0 \pm 1.0^{\mathrm{a}}$ & $20.3 \pm 1.5^{\mathrm{b}}$ & $16.2 \pm 0.5^{\mathrm{a}}$ \\
\hline
\end{tabular}

Data represent mean \pm standard deviation. PW1, PW2, propolis ethanol extract collected during winter from the Pueblo of Alamos and Rancho Viejo region, respectively; PS1, PS2, propolis ethanol extract collected during summer from the pueblo of Alamos and Rancho Viejo region, respectively. Different superscripts in rows indicate differences between treatments $(P<0.05)$.

Table 2. Microbial counts of raw propolis samples.

Tabla 2. Recuentos microbianos de muestras de propóleos.

\begin{tabular}{lcccc}
\hline Bacteria (CFU/g) & PW1 & PS1 & PW2 & PS2 \\
\hline Mesophilic & $<250$ & $<250$ & $<250$ & $<250$ \\
Psychrotrophic & $<250$ & $<250$ & $<250$ & $<250$ \\
Staphylococcus aureus & $<10$ & $<10$ & $<10$ & $<10$ \\
\hline
\end{tabular}

PW1, PW2, propolis ethanol extract collected during winter from the Pueblo of Alamos and Rancho Viejo region, respectively; PS1, PS2, propolis ethanol extract collected during summer from the pueblo of Alamos and Rancho Viejo region, respectively. re 1 , the results showed significant concentration-dependent differences $(P<0.05)$ in TPC and TFC between the analyzed samples. The highest $(P<0.05)$ TPC and TFC $(>200 \mathrm{mg}$ GAE/g and $>300 \mathrm{mg} \mathrm{QE} / \mathrm{g}$ at $250 \mu \mathrm{g} / \mathrm{mL}$, respectively) were obtained in propolis samples collected during summer (PS1 and PS2). In agreement with our work, higher TPC and TFC were found in propolis samples collected in semiarid regions during summer than winter (Valencia et al., 2012). It has also been reported that the season of collection quantitatively affects the chemical composition of Sonoran and Brazilian propolis extracts (Valencia et al., 2012; Bueno-Silva et al., 2017). In addition, phenolic compounds, major phytochemical groups found in honey bee products, have been shown to possess antibacterial and antioxidant properties (Falcão et al., 2013; NOM, 2017).

\section{Antibacterial activity of propolis extracts}

Propolis extracts and some standards were tested against foodborne pathogens (Table 3). The results showed that propolis sample $\times$ concentration had a significant effect $(P<0.001)$ on the antibacterial activity. The concentration used was greater efficacy $(P<0.05)$ against Gram-positive

A)
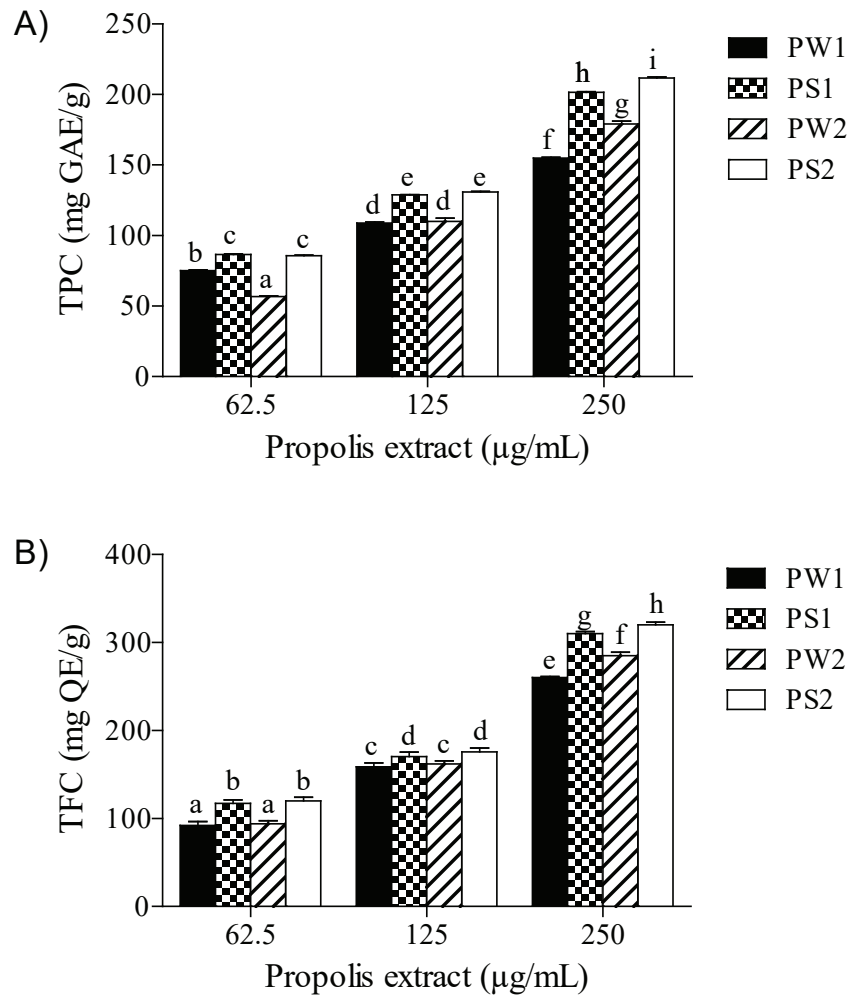

Fig. 1. Total phenolic (A) and total flavonoid (B) content of propolis extracts. Different superscripts indicate differences between treatments $(P<0.05)$. PW1, PW2, propolis ethanol extract collected during winter from the Pueblo of Alamos and Rancho Viejo region, respectively; PS1, PS2, propolis ethanol extract collected during summer from the Pueblo of Alamos and Rancho Viejo region, respectively.

Fig.1. Contenido total de fenoles (A) y flavonoides (B) de extractos de propóleos. Diferentes superíndices indican diferencias entre tratamientos $(P<0.05)$. PW1, PW2, extracto etanólico de propóleos colectado durante el invierno de la región de Pueblo de Álamos y Rancho viejo, respectivamente; PV1, PV2, extracto etanólico de propóleos colectado durante el verano de la región de Pueblo de Álamos y Rancho viejo, respectivamente. 
Table 3. Antibacterial activity of propolis extracts against foodborne pathogens.

Tabla 3. Actividad antibacteriana de extractos de propóleos contra patógenos transmitidos por alimentos.

\begin{tabular}{|c|c|c|c|c|c|}
\hline \multirow[t]{2}{*}{ Treatment } & \multirow[t]{2}{*}{$\begin{array}{l}(\mu \mathrm{g} / \\
\mathrm{mL})\end{array}$} & \multicolumn{2}{|c|}{$\begin{array}{c}\text { Gram-positive } \\
\text { bacteria }\end{array}$} & \multicolumn{2}{|c|}{$\begin{array}{c}\text { Gram-negative } \\
\text { bacteria }\end{array}$} \\
\hline & & $\begin{array}{c}L . \\
\text { monocytogenes }\end{array}$ & $\begin{array}{c}\text { S. } \\
\text { aureus }\end{array}$ & $\begin{array}{l}E . \\
\text { coli }\end{array}$ & $\begin{array}{c}\text { S. } \\
\text { typhimurium }\end{array}$ \\
\hline Ethanol & - & -- & -- & -- & -- \\
\hline CAPE & 250 & $8.0 \pm 0.2^{b}$ & $22.5 \pm 0.7^{g}$ & -- & $12.5 \pm 0.7^{\mathrm{de}}$ \\
\hline $\mathrm{Pn}$ & 250 & -- & $16.0 \pm 0.7^{d}$ & -- & -- \\
\hline Qc & 250 & $11.0 \pm 0.2^{c}$ & $12.5 \pm 0.1^{c}$ & -- & $6.5 \pm 0.7^{a}$ \\
\hline \multirow[t]{3}{*}{ PW1 } & 250 & $15.5 \pm 0.7^{e}$ & $18.0 \pm 0.1^{\mathrm{e}}$ & -- & $10.0 \pm 1.4^{c}$ \\
\hline & 125 & $8.0 \pm 0.1^{b}$ & $9.0 \pm 0.1^{b}$ & -- & $6.5 \pm 0.7^{a}$ \\
\hline & 62.5 & -- & -- & -- & -- \\
\hline \multirow[t]{3}{*}{ PS1 } & 250 & $12.5 \pm 0.7^{d}$ & $20.0 \pm 1.4^{\mathrm{fg}}$ & -- & $13.5 \pm 0.7^{e}$ \\
\hline & 125 & $7.0 \pm 0.1^{\mathrm{a}}$ & $9.0 \pm 0.1^{b}$ & -- & $8.5 \pm 0.7^{b}$ \\
\hline & 62.5 & -- & -- & -- & -- \\
\hline \multirow[t]{3}{*}{ PW2 } & 250 & $13.5 \pm 0.7^{d}$ & $17.5 \pm 0.7^{\mathrm{de}}$ & -- & $9.5 \pm 0.7^{b c}$ \\
\hline & 125 & $7.0 \pm 0.1^{\mathrm{a}}$ & $9.0 \pm 0.1^{b}$ & -- & $6.5 \pm 0.7^{\mathrm{a}}$ \\
\hline & 62.5 & -- & -- & -- & -- \\
\hline \multirow[t]{3}{*}{ PS2 } & 250 & $11.5 \pm 0.7^{c}$ & $18.5 \pm 0.7^{\text {ef }}$ & -- & $11.5 \pm 0.1^{d}$ \\
\hline & 125 & $7.0 \pm 0.1^{a}$ & $8.0 \pm 0.1^{a}$ & -- & $7.0 \pm 0.7^{a}$ \\
\hline & 62.5 & -- & -- & -- & -- \\
\hline
\end{tabular}

Data represent mean \pm standard deviation. CAPE, caffeic acid phenethyl ester; Pn, pinocembrin; Qc, quercetin; PW1, PW2, propolis ethanol extract collected during winter from the pueblo of Alamos and Rancho Viejo region, respectively; PS1, PS2, propolis ethanol extract collected during summer from the Pueblo of Alamos and Rancho Viejo region, respectively. (--), no inhibition zone $(0-5 \mathrm{~mm})$. Different superscripts in the same column indicate differences between treatments $(P<0.05)$.

bacteria (S. aureus $>$ L. monocytogenes) than Gram-negative bacteria (S. typhimurium $>$ E. coli), which is consist with earlier research (Seidel et al., 2008; Nedji and Loucif-Ayad, 2014).

The propolis samples had no significant effect $(P>0.05)$ against $E$. coli. In addition, at $250 \mu \mathrm{g} / \mathrm{mL}$ the propolis samples collected during summer (PS1 and PS2) displayed greater bacterial inhibition against $S$. aureus and $S$. typhimurium than propolis samples PW1 and PW2 $(P<0.05)$. On the contrary, no significant effect $(P>0.05)$ on L. monocytogenes inhibition was observed between seasons. de Souza et al. (2014) noticed that propolis extracts possess antibacterial activity mainly against $S$. aureus, and the efficacy of this activity is affected by the season. Similarly, Chen et al. (2008) described the antibacterial activity against S. aureus, Streptococcus spp., Vibrio damsela, Bacillus cereus, and Bacillus subtilis, and was more efficacious for propolis collected during summer than winter.

NOM (2017) established that propolis extracts must exhibit a high inhibitory effect against $S$. aureus. In this study, the inhibition effect displayed by propolis samples against foodborne pathogens was similar to that of the antibacterial standards. Moreover, a positive and significant $(P<0.05)$ correlation was found between the antibacterial activity, and the TPC $\left(r^{2}=0.81\right)$ and TFC $\left(r^{2}=0.82\right)$. It has been reported that antibacterial activity of propolis phenolic compounds can be exerted in three ways: synergistically activate some antibiotics, decrease the bacterial pathogenicity, and directly inhibit the bacterial growth. Likewise, the effectiveness depends on the polyphenols structure relationship including their hydroxyl at special sites on the aromatic rings; the methylation of the hydroxyl groups; the lypopholicity of the aromatic rings; the presence of hydrophobic substituents (including alkyl chains, alkylamino chains, prenyl groups), and nitrogen or oxygen containing heterocyclic moieties. These usually enhance the activity for propolis antioxidant compounds (Xie et al., 2015; Allawi, 2019).

\section{Antioxidant activity of propolis extracts}

The presence of phenolic compounds in honey bee products is highly correlated with the antioxidant activity (Yucel et al., 2017). As shown in Table 3, propolis extracts and some phytochemicals present in the propolis extracts were tested as antioxidants. There was a significant effect $(P<0.001)$ of propolis sample $\times$ concentration on antioxidant activity.
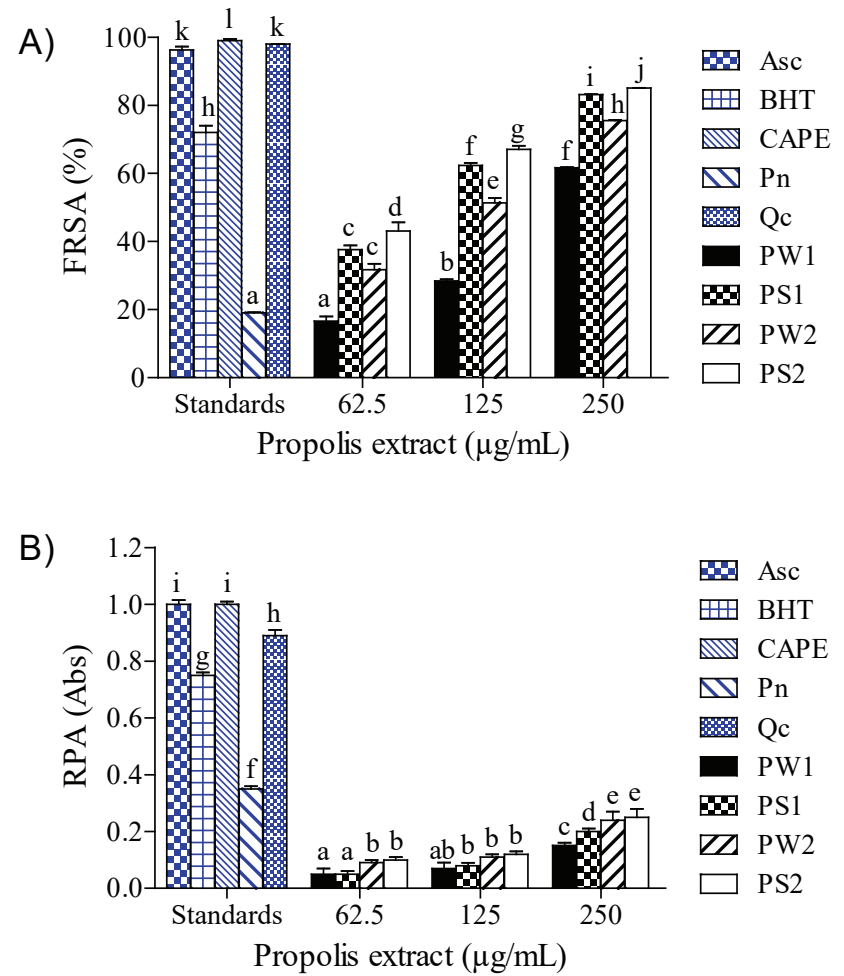

Fig. 2. Free-radical scavenging activity (A) and reducing power ability (B) of propolis extracts. Different superscripts indicate differences between treatments $(P<0.05)$. FRSA, free-radical scavenging activity; RPA, reducing power ability, Asc, ascorbic acid; BHT, butylated hydroxytoluene; CAPE, caffeic acid phenethyl ester; Pn, pinocembrin; Qc, quercetin; PW1, PW2, propolis ethanol extract collected during winter from the pueblo of Alamos and Rancho Viejo region, respectively; PS1, PS2, propolis ethanol extract collected during summer from the Pueblo of Alamos and Rancho Viejo region, respectively.

Fig.2. Actividad de eliminación de radicales libres (A) y habilidad de poder reductor (B) de extractos de propóleos. Diferentes superíndices indican diferencias entre tratamientos $(P<0.05)$. AERL, actividad de eliminación de radicales libres; HPR, habilidad de poder reductor, Asc, ácido ascórbico; BHT, hidroxitolueno butilado; EFAC, éster fenetílico del ácido cafeico; Pn, pinocembrina; Qc, quercetina; PI1, PI2, extracto etanólico de propóleos colectado durante el invierno de la región de Pueblo de Álamos y Rancho viejo, respectivamente; PV1, PV2, extracto etanólico de propóleos colectado durante el verano de la región de Pueblo de Álamos y Rancho viejo, respectivamente. 
As shown in Figure 2, regardless of the concentration used, the highest FRSA $(P<0.05)$ was obtained in propolis samples collected during summer ( 83.2 and $85.1 \%$ of radical inhibition for PS1 and PS2, respectively). In addition, all propolis samples had a weak FRSA in comparison to the antioxidant standards (CAPE, 99\%; Qc, 98\%; Asc, 96\%; BHT, 72\%; Pn, 19\%). However, at 125 and $250 \mu \mathrm{g} / \mathrm{mL}$, propolis collected during winter showed a radical inhibition above $50 \%$.

Moreover, the season had no impact on RPA $(P>0.05)$. The highest RPA $(P<0.05)$ was registered in propolis samples ( 0.24 abs) collected in the second zone (PW2 and PS2). However, all propolis samples had a weak RPA in comparison with the antioxidant standards (Asc, 1.0 abs; CAPE, 1.0 abs; Qc, 0.89 abs; BHT, 0.75 abs; Pn, 0.35 abs). FRSA had a positive and significant $(P<0.05)$ correlation with TPC $\left(r^{2}=0.99\right)$ and TFC $\left(r^{2}=0.98\right)$, while a weak correlation was found between RPA with TPC $\left(r^{2}=0.73\right)$ and TFC $\left(r^{2}=0.72\right)$. Consistent with these data, Chen et al. (2008) registered a higher FRSA for propolis collected during summer than winter, and a positive correlation $\left(r^{2}>0.9\right)$ has already been found between FRSA with the TPC and TFC of propolis samples (da Silva et al., 2006).

\section{CONCLUSIONS}

In conclusion, the physicochemical parameters, phenolic composition, and biological properties of raw Sonora propolis were affected by the season and geographical region of collection. Propolis samples collected during summer presented the highest total phenolic and total flavonoids contents, as well as the highest FRSA and RPA, and displayed greater antibacterial activity against Gram-positive bacteria than Gram-negative bacteria. Therefore, propolis extracts possess promising bioactive compounds with pharmacological and preservative properties.

\section{ACKNOWLEDGMENTS}

Rey D. Vargas-Sánchez gratefully acknowledgments a fellowship from CONACyT.

\section{REFERENCES}

Ainsworth, E.A. and Gillespie, K.M. 2007. Estimation of total phenolic content and other oxidation substrates in plant tissues using Folin-Ciocalteu reagent. Nature Protocols. 2(4):875-877. https://doi.org/10.1038/nprot.2007.102

ANZFA. Australia New Zealand Food Authority. 2000. P154 - Regulatory requirements for royal jelly, bee pollen and propolis and their products, including the need for label warning statements. [Accessed November 23, 2019] Available in: https://www.foodstandards.gov.au/code/ proposals/documents/P154\%20IR.pdf

Allawi, M.Y. 2019. Studying the synergistic effect of both propolis extract and green apple peel extract with fluconazole against Candida albicans. Rafidain Journal of Science. 28(1):7-12. https://doi.org/10.33899/rjs.2019.159396

AOAC. Association of Official Analytical Chemists. 2005. Official methods of analysis. (18th ed). Washington, DC: AOAC International.
Bankova, V., Bertelli, D., Borba, R., Conti, B.J., da Silva Cunha, I.B., Danert, C., Eberlin, M.N., Falcão, S.I., Isla, M.I., Moreno, M.I.N., Papotti, G., Popova, M., Santiago, K.S., Salas, A., Helena, A.C., Sawaya, F., Schwab, N.V., Sforcin, J.M., Simone-Finstrom, M., Spivak, M., Trusheva, B., Vilas-Boas, M., Wilson, M. and Zampini, C. 2019. Standard methods for Apis mellifera propolis research. Journal of Apicultural Research. 58(2):149. https://doi.org/10.1080/00218839.2016.1222661

Braakhuis, A. 2019. Evidence on the health benefits of supplemental propolis. Nutrients. 11(11):2705. https://doi. org/10.3390/nu11112705

Bueno-Silva, B., Marsola, A., Ikegaki, M., Alencar, S.M. and Rosalen, P.L. 2017. The effect of seasons on Brazilian red propolis and its botanical source: chemical composition and antibacterial activity. Natural Product Research. 31(11):1318-1324. https://doi.org/10.1080/14786419.2016.1239088

Chen, Y.W., Wu, S.W., Ho, K.K., Lin, S.B., Huang, C.Y. and Chen, C.N. 2008. Characterisation of Taiwanese propolis collected from different locations and seasons. Journal of the Science of Food and Agriculture. 88(3):412-419. https://doi. org/10.1002/jsfa.3101

CIE. Commission International de I’Eclairage. 1978. Recommendations on uniform color spaces, color-difference equations, psychometric color terms. Supplement 2 to $\mathrm{CIE}$ publication 15 (E1.3.1)/1971/(TC1.3). Vienna: Central Bureau of the CIE.

Cottica, S.M., Amado, D.A.V., de Aguiar, S.C., Boeing, J.S., Franco, S.L., Zeoula, L.M. and Visentainer, J.V. 2019. Antioxidant activity and lipid oxidation in milk from cows with soybean oil and propolis extract added to their feed. Food Science and Technology. 39(2):467-474. http://dx.doi.org/10.1590/ fst.33817

Drescher, N., Klein, A.M., Schmitt, T. and Leonhardt, S.D. 2019. A clue on bee glue: new insight into the sources and factors driving resin intake in honeybees (Apis mellifera). PloS ONE. 14(2):e0210594. https://doi.org/10.1371/journal. pone.0210594

Falcão, S.I., Freire, C. and Vilas-Boas, M. 2013. A proposal for physicochemical standards and antioxidant activity of Portuguese propolis. Journal of the American Oil Chemists Society. 90(11):1729-1741. https://doi.org/10.1007/s11746013-2324-y

Ghisalberti, E.L. 1979. Propolis: a review. Bee World. 60(2):59-84. https://doi.org/10.1080/0005772X.1979.11097738

Hernández, J., Goycoolea, F.M., Quintero, J., Acosta, A., Castañeda, M., Domínguez, Z., Robles, R., Vázquez-Moreno, L., Velázquez, E.F., Astiazaran, H., Lugo, E. and Velázquez, C. 2007. Sonoran propolis: chemical composition and antiproliferative activity on cancer cell lines. Planta Medica. 73(14):1469-1474. https://doi.org/10.1055/s-2007-990244

Letullier, C., Manduchet, A., Dlalah, N., Hugou, M., Georgé, S., Sforcin, J.M. and Cardinault, N. 2020. Comparison of the antibacterial efficiency of propolis samples from different botanical and geographic origins with and without standardization. Journal of Apicultural Research. 59(1):1924. https://doi.org/10.1080/00218839.2019.1681117

Lozina, L.A., Peichoto, M.E., Acosta, O.C. and Granero, G.E. 2010. Estandarización y caracterización organoléptica y físico-química de 15 propóleos Argentinos. Latin American Journal of Pharmacy. 29:102-110.

Molyneux, P. 2004. The use of the stable free radical diphenylpicrylhydrazyl (DPPH) for estimating antioxidant activity. Songklanakarin Journal of Science and Technology. 26(2):211-219. 
Nedji, N. and Loucif-Ayad, W. 2014. Antimicrobial activity of Algerian propolis in foodborne pathogens and its quantitative chemical composition. Asian Pacific Journal of Tropical Disease. 4(6):433-437. https://doi.org/10.1016/ S2222-1808(14)60601-0

NOM. NORMA Oficial Mexicana. 1994a. NOM-110-SSA1-1994, Bienes y servicios. Preparación y dilución de muestras de alimentos para su análisis microbiológico. [Accessed November 23, 2019] Available in: http://www.salud.gob.mx/ unidades/cdi/nom/110ssa14.html

NOM. NORMA Oficial Mexicana. 1994b. NOM-115-SSA1-1994, Bienes y servicios. Método para la determinación de Staphylococcus aureus en alimentos. [Accessed November 23, 2019] Available in: http://www.salud.gob.mx/unidades/ cdi/nom/115ssa14.html

NOM. NORMA Oficial Mexicana. 2017. NOM-003-SAG/GAN2017, Propóleos, producción y especificaciones para su procesamiento. [Accessed November 23, 2019] Available in: https://normateca.agricultura.gob.mx/sites/default/ files/normateca/Documentos/norma_oficial_mexicana_ nom_003_sag_gan_2017_propoleos_produccion_y_ especificaciones_para_su_procesamiento.pdf

NSO. Norma Salvadoreña. 2003. NSO 65.19.02:03, Calidad del propóleo crudo. [Accessed November 23, 2019] Available in: https://www.oirsa.org/contenido/2017/El_Salvador_ INOCUIDAD/8.\%20NSO\%2065\%2019\%2002\%2003\%20 -\%20CALIDAD_DE_PROPOLEO_CRUDO.pdf

Oyaizu, M. 1986. Studies on products of browning reaction. Japanese Journal of Nutrition and Dietetics. 44(6):307-315. https://doi.org/10.5264/eiyogakuzashi.44.307

Papotti, G., Bertelli, D., Bortolotti, L. and Plessi, M. 2012. Chemical and functional characterization of Italian propolis obtained by different harvesting methods. Journal of Agricultural and Food Chemistry. 60(11):2852-2862. https://doi.org/10.1021/ jf205179d

Pérez, B.R., Carrillo, J.G.P., Martínez, M.M.C., Mora, R.A.L. and Sánchez, T.A.C. 2019. Potencialización de la actividad antifúngica de propóleos Mexicanos con la adición de chalconas sintetizadas [Potentialisation of the Mexican propolis antifungal activity by the addition of synthetic chalcones]. Biotecnia.21(3):76-85. https://doi.org/10.18633/ biotecnia.v21i3.1014

Rennie, R.P., Turnbull, L., Brosnikoff, C. and Cloke, J. 2012. First comprehensive evaluation of the MIC evaluator device compared to Etest and CLSI broth microdilution for MIC testing of aerobic Gram-positive and Gram-negative bacterial species. Journal of clinical microbiology. 50(4):1147-1152. https://doi.org/ 10.1128/JCM.05395-11

Seidel, V., Peyfoon, E., Watson, D.G. and Fearnley, J. 2008. Comparative study of the antibacterial activity of propolis from different geographical and climatic zones. Phytotherapy Research. 22(9):1256-1263. https://doi. org/10.1002/ptr.2480 da Silva, J.F.M., de Souza, M.C., Matta, S.R., de Andrade, M.R. and Vidal, F.V.N. 2006. Correlation analysis between phenolic levels of Brazilian propolis extracts and their antimicrobial and antioxidant activities. Food Chemistry. 99(3):431-435. https://doi.org/10.1016/j.foodchem.2005.07.055

de Souza, E.A., Inoue, H.T., Fernandes Júnior, A., Veiga, N. and, de Oliveira Orsi, R. 2014. Influence of seasonality and production method on the antibacterial activity of propolis. Acta Scientiarum Animal Sciences. 36(1):49-53. http:// dx.doi.org/10.4025/actascianimsci.v36i1.21436

Tugba Degirmencioglu, H., Guzelmeric, E., Yuksel, P.I., Kırmızıbekmez, H., Deniz, I. and Yesilada, E. 2019. A new type of Anatolian propolis: Evaluation of its chemical composition, activity profile and botanical origin. Chemistry \& Biodiversity. 16(12):e1900492. https://doi.org/10.1002/ cbdv.201900492

USDA. United States Department of Agriculture. 1985. United States standards for grades of extracted honey. [Accessed November 23, 2019] Available in: https://www.ams. usda.gov/sites/default/files/media/Extracted_Honey_ Standard\%5B1\%5D.pdf

Valencia, D., Alday, E., Robles-Zepeda, R., Garibay-Escobar, A., Galvez-Ruiz, J.C., Salas-Reyes, M., Jiménez-Estrada, M., Velazquez-Contreras, E., Hernandez, J. and Velazquez, C. 2012. Seasonal effect on chemical composition and biological activities of Sonoran propolis. Food Chemistry. 131(2):645651. https://doi.org/10.1016/j.foodchem.2011.08.086

Vargas-Sánchez, R.D., Peñalba-Garmendia, M.C., SánchezEscalante, J.J., Torrescano-Urrutia, G.R. and SánchezEscalante, A. 2016. Pollen profile of propolis produced on the eastern edge of the Sonoran Desert in central Sonora, Mexico. Acta Botánica Mexicana. 114:69-86.

Xie, Y., Yang, W., Tang, F., Chen, X. and Ren, L. 2015. Antibacterial activities of flavonoids: structure-activity relationship and mechanism. Current Medicinal Chemistry. 22(1):132-149.

Yucel, B., Topal, E. and Kosoglu, M. 2017. Bee Products as Functional Food, Superfood and Functional Food - An Overview of Their Processing and Utilization. [Accessed November 23, 2019] Available in: https://www.intechopen. com/books/superfood-and-functional-food-an-overviewof-their-processing-and-utilization/bee-products-asfunctional-food

Zhishen, J., Mengcheng, T. and Jianming, W. 1999. The determination of flavonoid contents in mulberry and their scavenging effects on superoxide radicals. Food Chemistry. 64(4):555-559. https://doi.org/10.1016/S03088146(98)00102-2 